\title{
Women on corporate boards of directors: international issues and opportunities $^{1}$
}

\section{Ronald J. Burke and Susan Vinnicombe}

This collection addresses growing international interest in women on corporate boards of directors. But why a book on corporate women directors now?

The first research-based book (Burke and Mattis, 2000) appeared almost ten years ago. Since then, both international research and business interest has spiraled in terms of examining the role and number of women on corporate boards. Back in 2000 only the USA regularly measured the number of women on top corporate boards. Now more than 12 countries are regularly reviewing the gender balance of their top boards. It seemed time to take stock of what had transpired in these areas since 2000. Several journal articles (for example, Adams and Flynn, 2005; Burgess and Tharenou, 2002; Daily and Dalton, 2003; Vinnicombe and Singh, 2004), a few books (for example, Branson, 2007; Huse, 2007; Thomson and Graham, 2005), and some government reports (for example, Brown et al., 2003) have appeared in this time period. It seems that there have been several important developments since that time, some positive and some negative, having implications for women's representation on these boards.

Let us first consider the bad news. This includes:

- slow progress of women to senior management ranks, the pool from which many directors are selected;

- slow increase (glacial to some) in number of women on corporate boards;

- women continue to face the same challenges in being selected for board membership (e.g. the old boys' network, gender bias);

- decreases in the size of corporate boards;

- fewer women executive or inside directors in some countries;

- weak government monitoring of the status of women serving on corporate boards; 
- little interest in government intervention, often couched by opponents as 'quotas';

- a small number of international researchers studying board composition and its effects, and the experiences and contributions of women and minorities to board;

- the dramatic failure of corporate governance in many countries;

- a shortage of all directors as directors retire or choose to serve on fewer boards since board service has become more demanding and risky.

Let us turn now to the good news. This includes:

- a need for more and more qualified directors;

- legislative efforts in an increasing number (but still few) countries requiring a fixed percentage of board seats be held by women or other designated groups (e.g., Norway, Spain, South Africa, Sweden);

- government studies and inquiries into the state of corporate governance (e.g., the UK, USA, New Zealand, Canada, among others);

- greater board accountability and transparency;

- increasing efforts to evaluate board member contributions;

- increasing efforts to equip qualified women for selection to corporate boards (e.g. mentoring, use of placement firms, directories of qualified women);

- some educational and credential-providing programes for potential and actual directors delivered by schools of management and director institutes or associations;

- some 'soft' ratings of the best and worst corporate boards by business periodicals and newspapers;

- boards becoming more diverse;

- women directors now serve on more powerful board committees;

- women are bringing higher levels of human and social capital to their boards;

- more stakeholder activism for justice and change.

Considering the bad news and good news, we were surprised at the length of the listing of good news items. There seem to be some reasons for optimism as far as the future is concerned. We may be at a 'tipping point' in increasing women's representation on corporate boards, particularly if these items link together. This was one of the motivations for bringing our international authors and consultants together here.

What is the current international situation pertaining to women serving on corporate boards of directors, what has happened in the past ten years, 
and what are some of the important factors that have been found to affect women's representation on boards of directors? We will review a few here, leaving it to the chapters that follow to expand on these while adding several others.

1. Though women's representation on corporate boards of directors is, on average, low and relatively slow in changing, there is considerable variation in these figures across countries. Data from the top 50 firms in 29 European countries showed an average of 10 per cent, with a high of over 30 per cent in Norway to a low of 2 per cent in Italy and Malta.

2. The use of legislated quotas in a few European countries has produced positive change. Norway has legislated for 40 per cent female board representation with penalties for non-compliance. Recent Norwegian data indicate a 37 per cent participation rate in the companies registered on the Oslo stock exchange; Spain is considering a 40 per cent female representation rate compared to its present 5 per cent; and Sweden has proposed legislation for a mandatory 25 per cent participation rate for women. But targets (or quotas) are unlikely in many other countries (e.g., UK, USA, Canada).

3. Three different stakeholder approaches to increasing women's representation on boards have been identified over the past decade. These are: coercive - the use of government legislation (Norway, Sweden and Spain); liberal - organizations will voluntarily consider appointing women to corporate boards because it is the right thing to do (US, Canada); collaborative - a cooperative approach across various stakeholder groups (UK).

4. Various levers work simultaneously to increase women's board representation. These include: legal (equity legislation, anti-discrimination measures); corporate governance frameworks mandating an increasing number of independent directors on boards' lobbying from the media; the engagement of Chairmen and CEOs and the visibility/ prestige attributed to companies with increasing numbers of women on their boards.

5. Firms having more women directors being seen as employers of choice, particularly those organizations operating close to their customers. The reputation of an organization having more women directors may be heightened, since this is seen as a sign of good governance, an indicator of good management, shows more sensitivity to the needs of stakeholders in general, is seen as more ethical and socially just, and it develops better relationships, especially with female stakeholders. 
6. Women directors are more likely to be found in larger organizations, particular industries (retail, banking) and in organizations whose boards are linked to other boards that have women directors (Hillman et al., 2007)

7. There is an obvious need to consider the wider national environmentsocial, political and economic - to understand women's representation on boards of directors, though this has received little attention to date. Women's representation on boards is likely to be associated with women's representation in senior management, with the sizes of the gap in pay levels of women in relation to men, the presence of equality legislation, the availability of work-family initiatives and support in the society, and broader cultural values such as masculinityfemininity.

8. There is some evidence that having more women on a board increases the quality of board deliberations and corporate governance as a whole (Clarke, 2005; Fondas and Sassalos, 2000; Huse and Solberg, 2006; Stephenson, 2004; Van der Walt and Ingley, 2003).

9. There is some preliminary evidence that organizations having more women on their boards are more profitable (Erhardt et al., 2003; Zahra and Pearce, 1989).

10. There seem to be common barriers that women face across many countries that keep their representation on boards of directors low and relatively unchanging. These include: the attitudes of male chairmen and CEOs and male board members that favour other males, the old boys' network, the reluctance of search consultants to promote women, women seen as lacking line or bottom-line responsibilities in their careers, work and family responsibilities, and women not actively seeking board placements (Bilimoria and Piderit, 1999; Sheridan and Milgate, 2003).

\section{OBJECTIVES OF THIS VOLUME}

We see this collection as being of interest to both academic and business management constituencies. In addition, interest in board composition, board functioning, and board and organizational effectives is growing in all developed countries and many developing ones (for example, China, Russia). Corporate governance is increasingly being taught in business programs as a result of greater emphasis being placed on business ethics and corporate governance more generally. In addition, academics interested in women in management and workforce diversity more broadly will find this volume important and useful. There is also an increasing emphasis in 
executive sessions targeted at both women and men interested in serving as corporate directors. In Canada, for example, typically a quarter of the graduates of these offerings are women, a figure much higher than the percentage of women currently holding board seats. It is too soon to tell, however, whether these professional development programs will bear fruit. Women interested in achieving board seats would also benefit from various practical advice offered here. Companies interested in attracting and recruiting women directors would find the best practice information of immense value. In addition, as more countries undertake a variety of initiatives to increase women's representation on corporate boards through legislation, suggestions for supporting women through the creation of mentoring and networking opportunities and through developing lists of board-ready women are described.

This collection is divided into two main parts, followed by a concluding chapter. The first part presents status reports and recent initiatives taking place in 11 different countries. The reader will see both similarities and differences in these countries. The second part highlights central themes generated by recent research that help us understand both the issues and the opportunities facing qualified women and enlightened board chairs and CEOs interested in appointing more women to their boards of directors. As some have suggested, this is not only the 'right thing' but the 'bright thing' to do.

\section{OVERVIEW OF THE CONTENT}

The first part, International perspectives, includes ten chapters and offers a summary of the status of women directors and current research findings in each of the countries.

Lois Joy notes slow progress for women directors in the US. Women held 9.6 per cent of Fortune 500 board seats in 1995 and 14.6 per cent in 2006; this represented an increase of half a percentage point each year. In spite of this slow rate of growth some companies have maintained a critical mass of women ( 25 per cent or more) on their boards for more than 10 years. The chapter reports on interviews with women directors from a number of these 'sustained-commitment companies'. Joy concludes with a case study of the Chubb Corporation, where the board is central to the diversity and inclusion efforts of the business.

Ronald Burke and Richard Leblanc review developments in Canada. Interest in women directors is increasing here. Women held 9.9 per cent of directorships in 2001, up from 6.2 per cent three years earlier. But more than half the firms in the Financial Post 500 had no women directors. They 
identify four ongoing challenges women directors face in achieving directorships: director qualifications, director selection, director evaluation and director replacement. Each challenge is discussed with suggestions for countering it. Particular attention is given to the concept of each board developing a competency matrix and assessing its directors against it. This would help the board to recognize that each director need not possess all/most of these competencies to make an effective contribution.

Ruth Sealy, Susan Vinnicombe and Val Singh report on the efforts of the International Centre for Women Leaders at Cranfield University School of Management to both monitor and influence organizational board demographics and composition of the FTSE 100, and more recently the FTSE 250. They have now conducted nine successive benchmarking studies of the FTSE 100. Over this time, they have noted modest gains; women now hold 11 per cent of total FTSE directorships. But the percentages of inside women directors have not changed during this time. However, women directors are being appointed to executive committees in increasing numbers. They review their findings on what it takes for women to be selected as directors and the characteristics of companies who now appoint women directors. They identify a huge pipeline of female talent to the boardroom.

Mairi Maclean and Charles Harvey examine women in the boardrooms in France. The French government does not actively monitor the number of women on corporate boards. The authors found that in 1998 only 4.4 per cent of directors of the top 100 companies in France were female. In addition they found that more women held executive directorships in France than in the UK. A number of these female directors in France owed their position to being family members of owners or founders. The state also played a role in that women directors were more likely to have attended a prestigious university, held senior government jobs or to have been appointed by government.

Rosanne Hawarden and Ralph Stablein explore the status of women directors in New Zealand. New Zealand has significantly more women directors in the public sector ( 35 per cent) as compared with the corporate business (private) sector ( 5 per cent) as a result of government affirmative action policies. Canadian data are also consistent with this difference. They suggest that the substantial progress of women directors in state-run businesses may serve as an experiment for countries considering legislated gender quotas. New Zealand has many aspiring directors listed on a number of databases.

Anne Ross-Smith and Jane Bridge consider women directors in Australia. They note that board sizes in Australia, as elsewhere, have been decreasing. Private companies are not 'required' to have female directors. 
Women held 8.7 per cent of board seats on the top 200 companies in 2007, up from 8.2 per cent in 2002. More women in Australia, as in other countries, hold 'non-executive' directorships (outside appointees) than 'executive' directorships (inside appointees) as well. Corporate search firms and the government have set up various registers of women interested in serving on boards and this helps to bring qualified women to the attention of organizations.

Marit Hoel describes the story of Norway's introduction of the quota system as a law in 2003 . The law aimed at achieving 40 per cent female representation on the boards of all public limited companies. On 1 December 2007, 37 per cent of board directors were female, the highest percentage of any country in the world. The structure of boards in Norway is, however, different from the US and UK in that some directors have representation by virtue of their large ownership of shares, direct relationship with the owners, or they are elected by the employees.

Thoranna Jónsdóttir presents a status report on women directors in Iceland. Iceland ranks high in terms of gender equality, equal opportunity and percentage of women in the workforce. Research on women directors in Iceland is relatively new. Women held 12 per cent of the board memberships in 2005, but only 8 per cent in 2007 . The Icelandic government is actively studying this situation with the intention of increasing these numbers. A greater proportion of women than men hold more than one board seat.

Celia de Anca reviews developments in Spain. Companies in Spain, as elsewhere, must report their governance structure and practices to the national government. Women comprised 6.1 per cent of directors in 2006; about half of Spanish listed companies had at least one women director. A new Equality Law was introduced in 2007 recommending that 40 per cent of board members should be women by 2015 (but not quotas), fueling an intense debate on its merits. A number of initiatives have been developed to increase the number of qualified women to fill this gap.

Finally, Val Singh contrasts the positions of women directors in Jordan and Tunisia. No study to our knowledge had previously examined women on boards in Arab countries. In these countries, the family is particularly important and influential, more support is given to men than to women in their careers and connections to powerful others are vital for success. She provides a rich description of cultural values, governance structures and women's role in governance in these two interesting but not well understood societies. Women held about 2 per cent of the directorships in Jordan and 10 per cent of directorships in Tunisia. Tunisia compared favorably with several other countries. She concludes with a needed research agenda if we are to better understand governance in the Arab world, and 
suggestions for supporting women's progress in the workplace and in the boardroom.

The second part of this collection consists of eight chapters, each addressing a theme emerging and supported by research findings important for understanding the past, present and future of research and practice regarding women directors.

Nancy McInerney-Lacombe, Diana Bilimoria and Paul Salipante focus on the contributions women make to the effectiveness of board deliberations. They argue that women directors are particularly adept at raising and keeping difficult issues on the 'front burner' in board discussions. Based on interviews with senior directors, these authors develop a model of factors describing how women directors champion the discussion of difficult issues in boardroom deliberations. Their interviews highlighted the key role of group process in effective board discussions. A board of directors is essentially a small group, yet the roles and dynamics of group processes are only recently being applied to further extant understanding of board effectiveness.

Morten Huse also considers women directors' influence on board process and effectiveness (the 'black box' of board behavior) that includes, among other factors, what women bring to the boardroom, board leadership and structure, and the boardroom culture. This focus on board composition and board group process is consistent with recent work on improving board effectiveness. For too long, the 'black box' has been under-researched. The author describes the Value-creating Board Program as one way to look at actual board behavior, examining the unique and not-so-unique contributions of women directors.

Siri Terjesen, Val Singh and Susan Vinnicombe examine the central question of whether women still lack the 'right stuff' - the human capital - to sit as board directors on the FTSE 100. Are women still unqualified? They compared newly-appointed female and male directors on a number of biographical factors, for example: age, education, board experience, top management experience, professional experience and sector experience, among others. They conclude that there were relatively few differences between the male and female directors, and those differences that did appear were modest. Women directors had the right stuff; it was the attitudes and mindset of male directors that seemed to be the source of resistance.

Addressing why more women are not appointed to corporate boards of directors, Michelle Ryan, Clara Kulich, Alexander Haslam, Mette Hersby and Catherine Atkins suggest that women, more than men, are invited to join boards of poorer performing companies and have an increased risk of failure, which they term 'the glass cliff'. In addition, they suggest that women directors do not obtain the same rewards or punishments for their board services. Women directors were paid less when the organization was 
performing well and paid more when the organization was performing poorly. Thus women directors were rewarded less and punished less. This work highlights new challenges women may face at the top levels of organizations. But there was some good news in their findings; even 'glass cliff' appointments can have potential opportunities for women directors.

The chapter by Dan Dalton and Catherine Dalton examines the impact of the Sarbanes-Oxley (SOX) legislation in the US on women's positions as inside directors. Serving as an inside director is an important step to becoming a CEO. SOX may have generally limited directorships (for example: fewer directors on boards, fewer inside directorships); however, the authors find that SOX has not limited women's access to insider directorships. Having women in inside director roles is likely to support further increases in women's participation as corporate directors.

Susan Adams, Patricia Flynn and Toni Wolfman consider how the InterOrganization Network (ION) can be seen as a force for change in increasing women's representation on corporate boards. ION is a national organization of executive women's organizations in the US. They describe the development and history of ION, its structure and goals, and central activities. ION conducts research on the status of women, offers board recruitment assistance to organizations, provides training to current and prospective board members, shares best organization and board practices, and highlights the business case for greater board diversity.

Heather Foust-Cummings presents interview results from women directors serving on US corporate boards having relatively large numbers of women and a case study of an organization that has successfully achieved a more diverse board. Organizations can learn a lot from these best practices. Her data highlight how board diversity influences corporate business decisions and how company diversity is heightened by the actions of board members. Women board members act as models for women employees in the companies on whose boards they serve. Company commitment to board diversity is associated with a range of proactive initiatives which are described.

Sumru Erkut, Vicki Kramer and Alison Konrad examine how the number of women corporate directors on a board affects their ability to influence board dynamics. They conducted interviews and focus groups with women directors and search firm professionals who undertook recruiting for corporate boards. They concluded that the number of women on a board influenced the nature of leadership and influence exercised by women. Lone women were often seen as tokens or representatives of 'all' women. The presence of two women on a board validated each other and also influenced how men behaved. Having three or more women made women's presence 'normal'. Women on boards with three or more women 
directors were more comfortable being vocal and influential in boardroom discussions.

The final chapter concludes by looking at the future directions needed in the research on women on boards.

\section{NOTE}

1. Preparation of this manuscript was supported in part by York University, Canada and Cranfield University, UK.

\section{REFERENCES}

Adams, S.M. and P.M. Flynn (2005), 'Actionable knowledge: consulting to promote women on boards', Journal of Organizational Change Management, 13, 435-50.

Bilimoria, D. and S. Piderit (1999), 'Board committee membership: effects of sexbased bias', Academy of Management Journal, 37, 1453-77.

Branson, D.M. (2007), No Seat at the Table: How Corporate Governance and Law keep Women out of the Boardroom, New York: NYU Press.

Brown, D.A.H., D.I. Brown and V. Anastasopoulos (2003), 'Women on boards . . . not just the right thing but the "bright" thing', Ottawa: The Conference Board of Canada.

Burgess, Z.M. and P. Tharenou (2002), 'Women board directors: characteristics of the few', Journal of Business Ethics, 37, 39-50.

Burke, R.J. and M.C. Mattis (2000), Women on Corporate Boards of Directors: International Challenges and Opportunities, Dordrecht, NL: Kluwer.

Clarke, C.J. (2005), 'The XX factor in the boardroom: why women make better directors', Directors Monthly, August, pp. 12-14.

Daily, C.M. and D.R. Dalton (2003), 'Women in the boardroom: a business imperative', Journal of Business Strategy, 24, 8-10.

Erhardt, N.L., J.D. Werbel and C.B. Schrader (2003), 'Board of director diversity and firm financial performance', Corporate Governance: An International Review, 11, 102-11.

Fondas, N. and S. Sassalos (2000), 'A different voice in the boardroom: how the presence of women directors affects board influence over management', Global Focus, 12, 13-22.

Hillman, A.J., C. Shropshire and A.R. Cannella (2007), 'Organizational predictors of women on corporate boards', Academy of Management Journal, 50, 941-52.

Huse, M. (2007), Boards, Governance, and Value Creation, Cambridge: Cambridge University Press.

Huse, M. and A. Solberg (2006), 'How Scandinavian women make and can make contributions on corporate boards', Women in Management Review, 21, 113-30.

Sheridan, A. and G. Milgate (2003), "'She says, he says": Women's and men's views of the composition of boards', Women in Management Review, 16, 147-54.

Stephenson, C. (2004), 'Leveraging diversity to maximum advantage: the business case for appointing more women to boards', Ivey Business Journal, SeptemberOctober, 4-9. 
Thomson, P. and J. Graham (2005), A Woman's Place is in the Boardroom, Basingstoke: Palgrave.

Van der Walt, N. and C. Ingley (2003), 'Board dynamics and the influence of professional background, gender and ethnic diversity of directors', Corporate Governance: An International Review, 11, 218-34.

Vinnicombe, S. and V. Singh (2004), 'Why so few women directors in the top UK boardrooms? Evidence and theoretical explanations', Corporate Governance: An International Review, 12, 479-88.

Zahra, S.A. and J.A. Pearce (1989), 'Boards of directors and corporate financial performance: a review and integrated model', Journal of Management, 15, 291-334. 
Ronald J. Burke and Susan Vinnicombe - 9781848445192 Downloaded from PubFactory at 04/26/2023 02:39:10PM 